\title{
Karolina Karpus*
}

\section{The new Polish Act on Waste of 2012}

\author{
http://dx.doi.org/10.12775/PYEL.2013.003
}

\section{Summary}

The aim of this paper is the description of changes in the Polish law on waste connected with the passing and the implementation of the new main act for this branch of law, i.e. the Act on Waste of 14 December 2012 ${ }^{1}$. By means of this Act the Polish law on waste is being amended to the requirements resulting from the Directive 2008/98/EC of the European Parliament

* Doctor of Laws, assistant at the Environmental Law Protection Department of Nicolaus Copernicus University in Torun.

1 Journal of Laws of 2013, item 21 with amendments; further referred to as the Act on Waste of 2012; As far as the new Act on Waste of 2012 is concerned, see: Z. Bukowski, Zakres nowej ustawy o odpadach, Recykling 2013, No 2; M. Górski, Nowa ustawa o odpadach. Regiony $i$ regionalne instalacje, PK 2013, No 2; M. Górski, Nowe przepisy o odpadach. Reglamentacja wytwarzania odpadów, PK 2013, No 3; J. Jerzmański, Ustawa z 14 grudnia 2012 r. - Nowe zasady gospodarowania odpadami, PK 2013, No 2; A. Pacek-Łopalewska, Ustawa o odpadach: komentarz, Wrocław 2013; Ustawa o odpadach: komentarz, pod red. B. Rakoczego, Warszawa 2013; W. Radecki, Ustawa o odpadach: komentarz, Warszawa 2013. 


\section{Karolina Karpus}

and of the Council of 19 November 2008 on waste and repealing certain Directives ${ }^{2}$.

The description of the new Polish Act on Waste was presented, on the one hand, by the indication of new solutions resulting from the Directive 2008/98. On the other hand, the changes in comparison with the former binding act, i.e. the Act on Waste of 27 April 2001, were presented ${ }^{3}$.

\section{Key words}

Law on waste, waste management, recovery, disposal.

\section{Introduction}

The Polish law on waste is one of the branches of environmental protection law. It is currently a branch extensively developed by the Polish legislator, which is the result of the EU and international obligations of Poland in this field. The systematics of this branch is as follows:

a) the main act concerning the whole environmental protection law, i.e. the Act of 27 April $2001^{4}$ on the Environmental Protection Law;

b) the main act concerning the law on waste - currently the new Act on Waste of 2012;

c) specific acts within the law on waste concerning chosen kinds of waste or issues concerning waste management, including especially:

1) the Act of 16 March 1995 on the Prevention of Sea Pollution from Ships ${ }^{5}$,

2) the Act of 13 September 1996 on Maintaining Cleanliness and Order in Municipalities (the act applies to municipal waste) ${ }^{6}$,

3) the Act of 29 November 2000 on the Atomic Law

2 OJ L 312, 22.11.2008, p. 3-30.

3 Journal of Laws of 2010, No 185, item 1243 with amendments - repealed as of 23 January 2013; further referred to as the Act on Waste of 2001.

4 Journal of Laws of 2001, item 1232 with amendments; further referred to as the EPA.

5 Journal of Laws of 2012, item 1244.

6 Journal of Laws of 2013, item 391 with amendments.

7 Journal of Laws of 2012, item 264 with amendments (radioactive waste). 
4) the Act of 11 May 2001 on Producers' Obligations in the scope of Managing Certain Types of Waste and on Product Charges ${ }^{8}$,

5) the Act of 12 September 2002 on the Harbour Installations for the Reception of Waste and Cargo Remains from Ships ${ }^{9}$,

6) the Act of 20 January 2005 on the Recycling of End-of-life Vehicles ${ }^{10}$,

7) the Act of 29 July 2005 on Waste Electric and Electronic Equipment ${ }^{11}$

8) the Act of 29 June 2007 on International Movement of Waste ${ }^{12}$,

9) the Act of 20 July 2008 on Mining Waste ${ }^{13}$,

10) the Act of 24 April 2009 on Batteries and Accumulators ${ }^{14}$,

11) the Act of 13 June 2013 on Packaging and Packaging Waste Management ${ }^{15}$.

The above enumeration clearly indicates that the Polish regulations on waste are presented in several acts, which from the point of view of legislative technique and law efficiency should be assessed as unsatisfactory. The need to regulate waste management beyond the EPA may be justified. However, it is extremely difficult to find justification for the situation, in which waste and waste management are subject to 12 different acts, not counting executive acts (regulations and local law acts). It should be also mentioned that such a method of regulations present in the Polish law on waste is similar to the regulations present in the EU law on waste. Unfortunately, the EU legislator applies an approach 'new problem - new, separate directive'. The EU legislator implementing the new frame Directive 2008/98 made an attempt to consolidate law issues in this field, enclosing in the act regulations on hazardous waste and waste oils. Simultaneously, the Council Directive 91/689/EEC of 12 December 1991 on hazardous waste $^{16}$ and the Council Directive 75/439/EEC of 16 June 1975 on the disposal of waste oils ${ }^{17}$ were repealed as of 12 December 2010.

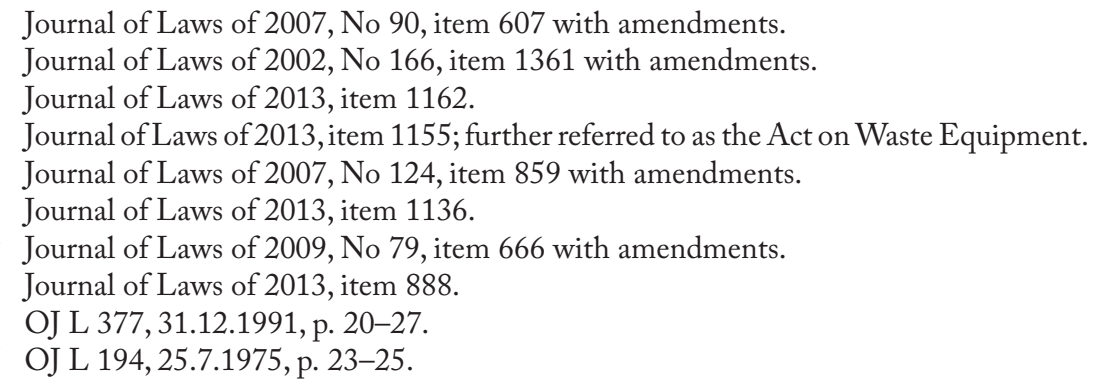

Journal of Laws of 2007, No 90, item 607 with amendments. Journal of Laws of 2002, No 166, item 1361 with amendments. Journal of Laws of 2013, item 1162.

Journal of Laws of 2013, item 1155; further referred to as the Act on Waste Equipment. Journal of Laws of 2007, No 124, item 859 with amendments. Journal of Laws of 2013, item 1136.

Journal of Laws of 2009, No 79, item 666 with amendments. Journal of Laws of 2013, item 888.

OJ L 377, 31.12.1991, p. 20-27.

OJ L 194, 25.7.1975, p. 23-25. 
The Polish legislator has already implemented, in the main act on waste, parts of specific issues concerning waste management, including above all the regulations implementing not only the Council Directive 91/689/EEC and the Council Directive 75/439/EEC but also the Council Directive 78/176/ EEC of 20 February 1978 on waste from the titanium dioxide industry ${ }^{18}$, the Council Directive 86/278/EEC of 12 June 1986 on the protection of the environment, and in particular of the soil, when sewage sludge is used in agriculture ${ }^{19}$, the Council Directive 1999/31/EC of 26 April 1999 on the landfill of waste ${ }^{20}$ and the Directive 2000/76/EC of the European Parliament and of the Council of 4 December 2000 on the incineration of waste ${ }^{21}$. However, the legislator did not make an effort to include, in the new main Act of 2012 on Waste, such issues as the management of municipal waste, packaging waste, batteries and accumulators, end-ofuse vehicles, mining waste and waste from ships. The lack of consolidation of regulations on waste in one coherent act shall be assessed critically.

The aim of the paper is the description of the main changes in the Polish law on waste connected with the passing and the implementation of the new main act for this branch of law, i.e. the Act on Waste of 14 December 2012. By means of this act, the Polish law on waste has been adjusted to the requirements resulting in the first place from the Directive 2008/98. The new Act on Waste is another act regulating general issues of the Polish law on waste. The previous acts were: the Act on Waste of 27 April 2001 (repealed as of 23 January 2013), the Act on Waste of 27 June $1997^{22}$ and the Act of 31 January 1980 on Environmental Protection and Management ${ }^{23}$, (more precisely - Section II Chapter 8 'Environmental Protection against Waste and other Pollutants'). The implementation of the new Act on Waste of 2012 opened the next stage of development of the Polish law on waste. As part of this stage, the Polish legislator deals with such constructions as the notion of a 'by-product','end-of-waste status'- presenting for the first time appropriate legal basis in this new act. Moreover, a partial organization of the Polish legal regulations concerning the instruments of waste
OJ L 54, 25.2.1978, p. 19-24.
OJ L 181, 4.7.1986, p. 6-12.
OJ L 182, 16.7.1999, p. 1-19.
OJ L 332, 28.12.2000, p. 91-111.
22 Journal of Laws of 1997, No 96, item 592 with amendments.
23 Journal of Laws of 1994, No 49, item 196 with amendments. 
management control took place, i.e. the implementation of new regulations such as the register of entities introducing products, products in packaging and managing waste, or the data base on products and packaging and waste management.

\section{The main changes in the new Act on Waste}

\subsection{General rules of waste management}

In Section I ('General rules'), as already mentioned above, next to the statutory definitions, the regulations implementing the Directive 2008/09 concerning the recognition of the object or substance as a by-product and the end-of-waste status were presented. Moreover, the Polish legislator introduced, in this part of the new Act of 2012, the regulations enabling to change the status of hazardous waste into non-hazardous waste, which is a new solution. According to article 8 section 1 of the Act, a waste holder is obliged to submit the notification of the classification change of hazardous waste into non-hazardous waste (along with the research results properties of waste designated to classification change) to the marshal of a voivodeship, competent regarding the place of waste production or management. The marshal of a voivodeship is a competent body within this scope and the marshal, on the grounds of a notion, issues a decision approving the classification change of hazardous waste into non-hazardous waste or a decision raising objection.

In Section II of the new Act on Waste of 2012, the Polish legislator presents in a broader sense the issues concerning general rules on waste management. In comparison with the Act of 2001, this group of regulations has been significantly extended. The technique of direct transposition from the Directive 2008/98 was applied. In accordance with the Directive, the hierarchy of waste management was modified, with the aim to put special pressure on the rule of prevention and the conception of 'recycling society', and within their frames on the activities implementing those values: the prevention of waste production, preparing for re-use and recycling.

The rule of proximity was extended, which was mainly related to the currently carried out reform within municipal waste management (on the 
grounds of the amended Act of 13 September 1996 on Maintenance of Cleanliness and Order in Municipalities). Within this scope, the Polish legislator adapted two units of territorial division of the state to determine the rule of proximity - a voivodeship (a unit of fundamental division of the state) and a region of municipal waste management (a unit of special division - inside a voivodeship).

On the other hand, in the case of 'pollutant pays principle' within waste management, the Polish legislator kept in the new Act of 2012 previous laconic regulations (article 22). It seems that more detailed presentation of this rule would be necessary in the range of the existing EU courts judicature within this scope, especially in the case of the regulations concerning entities bearing costs in the chain of waste distribution.

The part of provisions in Section II of the Act of 2012 concerning issues of waste storage may be counted as a new solution. For the first time, the Polish legislator described this activity in a broader sense, defining the circumstances justifying its conduct. It shall support the tightening of the waste management system.

\subsection{Waste management plans}

In Section III of the Act, the regulations of Section V of the Directive 2008/98 ('Plans and programmes') have been implemented. According to article 28 section 2 of the Directive 2008/98 'waste management plans' are plans setting out an analysis of the current waste management situation in the geographical entity concerned, as well as the measures to be taken to improve environmentally sound preparing for re-use, recycling, recovery and disposal of waste and and evaluation of how the plan will support the implementation of the objectives and provisions of this Directive. On the other hand, according to article 29 section 1-2 of this act 'waste prevention programmes' set out the waste prevention objectives. Member States shall describe the existing prevention measures and evaluate the usefulness of the examples of measures indicated in Annex IV or other appropriate measures.

Member States could choose whether the programmes would be integrated with waste management programmes or other programmes concerning environmental policy or if they would function as separate programmes. The EU legislator requires only to define exactly the waste prevention measures if the programme is integrated with the waste management programme 
or other programmes. The examples of waste prevention measures were indicated in Annex IV of the Directive 2008/98. The Polish legislator has chosen the first of the above-mentioned options, implementing only the main plan - 'waste management plan' with the indication that one of its elements are waste prevention objectives and measures. Annex V of the Act is the equivalent of Annex IV of the Directive 2008/98.

In the Act of 2001, the provisions concerning waste management plans were described in articles 14-16. Until 1 January 2012, on the grounds of article 14 section 3 of this Act, plans were elaborated at the level of the state, voivodeship, powiat and gmina. As a result of the amendment of article 14 of the Act of 2001, made on the grounds of article 4 section 4 of the Act of 1 July 2011 on amending the Act on Maintenance of Cleanliness and Order in Municipalities and some other acts ${ }^{24}$, from 1 January 2012 waste management plans are accepted only at the level of the state and voivodeship, which is also the accepted solution in the new Act on Waste. The national waste management plan and the voivodeship management plans approved on the grounds of former provisions became on the grounds of article 227 of the Act of 2012 plans as defined by the new Act.

In principle, the contents of both plans are in compliance with the requirements of the Directive 2008/98. It should be added that the voivodeship waste management plans, in accordance with article 35 section 4 of the Act of 2012, include following elements:

1) the division of the voivodeship into regions of municipal waste management along with indicating which gminas are included in the region;

2) the indication of regional installations for recycling of municipal waste in individual regions of municipal waste management and installations for substitute service of these regions in the case when the existing installation fails or it is not able to accept waste for other reasons and until regional installations for municipal waste recycling are opened;

3) the plan for closing installations, which do not comply with the environmental protection requirements, modernization of which is not possible due to technical reasons or is not economically justified.

24 Journal of Laws of 2011, No 152, item 897 with amendments. 
The above-mentioned solution concerns municipal waste management. While passing the new Act on Waste of 2012, the Polish legislator did not avail the opportunity to include provisions concerning municipal waste in the Act. Municipal waste is still subject to the provisions of the Act of 13 September 1996 on Maintenance of Cleanliness and Order in Municipalities (repeatedly amended). According to this Act municipal waste management is the task of gmina self-government. However, the Act on Waste of 2012 states that voivodeship self-government is also competent in this scope - including among other things such an important task as the division of a voivodeship into regions of municipal waste management. According to article 35 section 5 of the Act on Waste 'municipal waste management region is an area of neighbouring gminas with at least 150,000 inhabitants and which is serviced by installations mentioned in section 6; a region of municipal waste management may also be an area of a gmina with more than 500,000 inhabitants'.

Another solution accepted in the new Act on Waste is the resolution, which is the act of local law, on the accomplishment of the voivodeship waste management programme (article 38 of the Act of 2012). Unlike the plan, the resolution on the accomplishment of the voivodeship waste management programme is an act of common law. A resolution defines:

- regions of municipal waste management;

- regional waste recycling installations in individual regions of municipal waste management and installations for substitute service of these regions in the case the existing installation fails or it is not able to accept waste for other reasons and until regional installations for communal waste are opened.

\subsection{Permits required for waste management and register keeping (Section IV of the Act on Waste of 2012)}

In Section IV of the Act, Chapter IV of the Directive 2008/98 ('Permits and registrations' - articles 23-27) has been transposed. The accomplishment of this requirement involved the necessity to alter the former working model of ration on waste management. Especially important was a broader application of an instrument, i.e. the register, which according to article 26 of the Directive 2008/98 shall keep entities not subject to permit 
requirements, which in its current shape may be described as a consolidated register.

In Section IV Chapter 1, the legislator included provisions concerning issues of waste collection permits and waste recycling permits. In the Act of 2001 the provisions on administrative decisions issued on account of: a) waste production and b) waste management activities have been included.

In the group concerning waste production, the following administrative decisions have been presented:

- a permit for waste production ${ }^{25}$ - according to article 17 section 2 of the Act of 2001 a waste producer was obliged to obtain a permit in the case of waste, which is produced in connection with the exploitation of installations provided they produced more than $1 \mathrm{Mg}$ of hazardous waste per year or more than $5,000 \mathrm{Mg}$ of non-hazardous waste per year;

- a decision approving the programme of hazardous waste management - according to article 17 section 1 point 1 of the Act of 2001, a waste producer was obliged to obtain a decision if they produced more than $0.1 \mathrm{Mg}$ of hazardous waste per year;

- a decision approving the programme of waste management-according to article 17 section $1 \mathrm{a}$ of the Act of 2001, a waste producer was obliged to obtain a decision if they carried out the activities related to services within the scope of construction, demolition, renovation of buildings, cleaning tanks or devices and installations, conservation and repair and recycling of waste containing asbestos in transporting containers.

Moreover, within the administrative limitations concerning waste production according to article 17 section 1 point 2 in connection with article 24 of the Act of 2001 there was a so called simplified mode according to which the installation was reported to an administrative body ${ }^{26}$. This mode

25 At the same time, in the case of this permit the provisions were also included in the $\mathrm{EPA}$, and, moreover, the provisions on integrated permits were also in force (see: article 182 of the EPA).

26 See article 17 section 1 point 2 of the Act of 2001 - a waste producer shall submit the information on the waste produced and the manners of produced waste management if it produces hazardous waste in the amount of up to $0.1 \mathrm{Mg}$ per year or exceeding $5 \mathrm{Mg}$ per year of the non-hazardous waste, with the chance to make an objection by the competent body. 
was an alternative to administrative decisions and concerned submitting information on waste produced and the methods of waste management.

Whereas, in the group of decisions concerning waste management in the Act of 2001 there were (articles 26-32a):

- waste recovery and disposal permits;

- waste collection and transportation permits.

In the new Act of 2012, the legislator made considerable changes, which to some extent order and unify those solutions with the main act of the Polish environmental protection law, i.e. the Act of 2001 on Environmental Protection Law. In the present legal state, a waste producer, who produces more than $1 \mathrm{Mg}$ of hazardous waste per year or more than 5,000 Mg of non-hazardous waste per year, is still obliged to obtain a waste production permit, the difference being that they are subject to another legal basis. This obligation is currently described in article 180a of the EPA, whereas the other provisions are scattered throughout the whole Section IV of Title III of the EPA.

Moreover, in the current state of law the Polish legislator resigned from the simplified notion mode in the case of waste production. It is a result of establishing a new 'register of entities introducing products, products in packaging and managing waste'.

In the Act of 2012, the decisions within waste management were maintained, at the same time the change in this case is the introduction of:

- waste collection permits;

- waste recycling permits;

- waste collection and recycling permits.

The permits presented in the Act on Waste of 2001 were then slightly altered. At the same time, in the new legal state, the Polish legislator resigned from a separate waste transportation permit. In exchange, entities defined as 'waste transporting' according to article 50 section 1 point $5 \mathrm{~b}$ of the Act of 2012 are subject to entry into the register of entities introducing products, products in packaging and managing waste.

In Section IV Chapter 2 of the Act of 2012, the legislator introduced provisions concerning the new register of entities introducing products, products in packaging and managing waste, which is kept in accordance with article 49 section 1 by the marshal of a voivodeship.

In the former legal state in the Act of 2001 the legal basis of keeping following registers were presented: a) the register, kept by the right starost, of waste holders or persons carrying out the activity in the field 
of transportation of waste, which is exempted from the obligation to obtain a permit to carry out the activity in the field of collection, transportation, recovery or disposal of waste (article 33 section 5); b) the register, kept by the marshal of a voivodeship, of permits granted in the scope of waste production and management (along with a voivodeship data base kept by the marshal of a voivodeship and concerning the production and management of waste) (article 37 section 6); c) a commonly available list, kept by the Chief Environmental Protection Inspector, of persons running the installations for the regeneration of waste oils, meeting the requirements determined for those installations (article 39 section 1a). Moreover, the Chief Inspectorate of Environmental Protection was obliged on the grounds of specific provisions to: a) keep the register of entities placing on the market equipment, collecting waste equipment, operating recycling centres, carrying out the activity in the scope of recycling, carrying out recovering activities other than recycling, organisations operating within the scope of recovery of waste electric and electronic equipment (article 6 of the Act on Waste Electric and Electronic Equipment) and b) keep the register of entities placing batteries and accumulators on the market and entities operating facilities for processing of waste batteries or waste accumulators (article 17 of the Act on Batteries and Accumulators), as well as c) accept, from the entity bringing a vehicle, a notification on commencing the activity in the scope of production, import or intra-Community acquisition of a vehicle (article 13 section 1 of the Act on Vehicles Recycling). Whereas, the marshal of a voivodeship in accordance with article 9 section 1 of the Act on Producers' Obligations accepted a notification from the entity commencing the activity in the scope of production, import or intraCommunity acquisition of products in packaging, which are described in Annex 1 of this Act ('Sorts of packaging'), or products, which are described in in Annex 3of this Act ('Sorts of other products').

The new register of entities introducing products, products in packaging and managing waste, according to article 49 section 1 of the Act of 2012, is an instrument consolidating the above mentioned legal solutions in the hands of marshals of voivodeships only. The formation of the new register shall be completed not later than 23 January 2016. In the meantime, former solutions are still applied.

The new register of entities introducing products, products in packaging and managing waste shall fulfil two major functions: a) rationing (the entry into the register is the condition of conducting legal activities) and 
b) consolidating (understood as conducting activities in order to gain inner coherence of law on waste). The register provides for two kinds of entries: a) upon application (article 50 section 2 of the new Act on Waste) and b) ex officio (article 51 section 1 of the new Act on Waste). Rationing takes place in the case of entities obliged to obtain the entry into the register upon application and consolidation in the case of entities obtaining the entry into the register ex officio. It should be pointed out that according to article 49 section 6 of the new Act on Waste of 2012, the register is an integral part of 'The database on products and packaging and on waste management' (further referred to as the Database).

Obtaining the entry into the register upon application (as a condition of legal activities) is an obligation of entities subject to the following regulations:

1) the Act of 11 May 2011 on Producers' Obligations in the scope of Managing Certain Types of Waste and on Product Charges: a) introducing products to the national market; b) conducting activities in the scope of recovery or recycling of waste originating from production; c) recycling organizations; d) conducting activities in the scope of exports and intra-Community transfer of waste originated from the products with the aim to recover or recycle them;

2) the Act of 20 January 2005 on the Recycling of End-of-life Vehicles : a) introducing vehicles, b) operating vehicle collection facilities, c) operating dismantling facilities, d) operating shredders;

3) the Act of 29 July 2005 on Waste Electric and Electronic Equipment: a) introducing equipment and entities effectuating an intraCommunity acquisition of equipment, presented in article $3 \mathrm{a}$ section 1 of this Act, b) collecting waste equipment, c) operating recycling facilities, d) operating facilities within the scope of recovery of waste electric and electronic equipment, e) conducting activities in the scope of recycling, f) conducting recovery activities other than recycling;

4) the Act of 24 April 2009 on Batteries and Accumulators: a) introducing batteries and accumulators, b) operating waste batteries and accumulators facilities;

5) the new Act on Waste of 2012: a) waste holders conducting activities in the scope of recycling of waste exempt from the obligation of obtaining a waste recycling permit, b) entities transporting waste, c) waste sellers and middlemen in waste trade unless they are subject to enter the register on other grounds; 
6) the Act of 13 June 2013 on Packaging and Packaging Waste Management concerning entities which: a) are packaging recovery organisations, b) conduct an intra-Community delivery of: packaging waste, products in packaging, c) export: packaging waste, packaging, products in packaging, d) conduct activities within the scope of recycling or recovery activities in the scope of packaging waste other than recycling, e) introducing packaging, f)introducing products in packaging.

According to article 55 section 1 of the new Act on Waste, the marshal of a voivodeship, by making the entry into the register, creates an individual account in the Database. On account of that, the marshal of a voivodeship notifies the entered entity about the activation of the account and about the login and access password to the account. In accordance with article 56, the marshal of a voivodeship, as a register body, also conducts such activities as:

- the entry of required information on entities conducting activities in the scope of waste management into the register;

- the data loss protection, i.e. keeping and processing the information on entities entered into the register.

The marshal of a voivodeship is also a competent body to cross an entity off the register by means of an administrative decision, which can be done upon application (in the case of permanent cease of conducting activities, which require an entry into the register) or ex officio.

The part of entities subject to the obligation of the entry into the register, is obliged to pay a registration fee and then an annual fee. According to article 57 section 6 of the Act on Waste, the fees amount between PLN 50 and 2,000. According to article 58 section 2 of the Act, the revenues from registration and annual fees constitute $50 \%$ of the income of a voivodeship budget and $50 \%$ of the income of the state budget.

\subsection{Waste records and reporting in the scope of waste management}

In Section $V$ of the Act two issues are presented: keeping the wastes records (Chapter 1, articles 66-72) and the accomplishment of the obligation, i.e. reporting in the scope of waste management (Chapter 2, articles 73-78), at the same time the obligation also applies to the stage when certain things are in the phase of primal use. It concerns the following category of things: packaging, products in packaging, products mentioned 
in Annexes 1 and 3 of the Act of 11 May 2001 on Producers' Obligations in the scope of Managing Certain Types of Waste and on Product Charges, vehicles, electric and electronic equipment, batteries and accumulators. The legislator evidently attempts, in the new Act on Waste of 2012, to unify the requirements within the obligation to keep the waste records and reporting in the scope of waste management, overcoming, at least in this element, the unfavourable state of excessive dispersion of regulations in specific acts concerning these categories of things and dealing with them in the phase of their primal use and the phase of managing them as waste.

In the Directive 2008/98 the obligation of keeping the records was described in article 35, in the same time the EU legislator found that it shall be mandatory in the case of hazardous waste. Whereas, in the case of nonhazardous waste, Member States decide individually if the producers of nonhazardous waste are to comply with this obligation (article 35 section 3 ).

According to article 35 section 1 of the Directive 2008/98, the establishments or undertakings conducting waste recycling on the ground of a permit, the producers of hazardous waste and the establishments and undertakings which collect and transport hazardous waste on a professional basis, or act as dealers or brokers of hazardous waste, shall keep a chronological record of the quantity, nature and origin of the waste, and, where relevant, the destination, frequency of collection, mode of transport and treatment method foreseen in respect of the waste, and shall make that information available, on request, to the competent authorities. Whereas, in article 35 section 2 of the Directive, the EU legislator defined the period of preserving documents on hazardous waste - 'at least for three years', and in the case of establishments and undertakings transporting hazardous waste the records must be kept 'for at least 12 months'.

While implementing article 35 of the Directive 2008/98 in Section V of the Act of 2012, the Polish legislator has chosen an extended model of the obligation to keep waste records, i.e. also in reference to non-hazardous waste. In the case of the obligation of preserving waste records, the Polish legislator applied the general rule (article 72 section 1) - 'a five-year period from the end of year, in which the records were compiled'. It may be pointed out that the Polish legislator found it necessary to define this obligation more strictly that it is said in the Directive 2008/98.

The layout of Section V, presenting the waste records and reporting in the scope of waste management, gives an idea referring to the control of fulfilling, by the entities using the environment, the obligation 
of conducting appropriate waste management. In the case of the waste records the obligation of an individual entity has an inner, initial and parallel character (current records), whereas the obligation of reporting of this entity has an external (towards competent bodies), derivative (drawn up on the grounds of existing documents) and consequent (after the termination of the reporting period) character.

The lack of fulfilment of both obligations, i.e. the waste records and reporting, results in holding the legal liability. The Polish legislator, in the case of not fulfilling or the wrong fulfilling of the obligation of the waste records turns in article 180 of the new Act on Waste of 2012 to criminal liability - an offence subject to a fine. Whereas, in the second case - the obligation of reporting, defined in article 76 of the Act, the Polish legislator turns to administrative liability. According to article 200 section 1 of the new Act on Waste if the entity does not submit the report, they are subject to administrative fine of PLN 500, inflicted in the way of a decision of the competent voivodeship inspectorate of environmental protection, in the same time, the legislator introduces additional grounds to impose fines in higher amount (up to PLN 8,500 per year).

\subsection{Database on products and packaging and on waste management (the Database)}

In Section VI of the Act on Waste of 2012, the Polish legislator presents provisions concerning the new instrument of collecting and processing information on products and waste originating from them, which is the Database. The Database shall be created within 36 months from the implementation day of the Act of 2012, i.e. until 23 January 2016. According to article 238 section 4, in the period not longer than one year from the date of the creation of the database, the following data of currently kept databases, will be transferred to it:

1) the voivodeship data base ${ }^{27}$, concerning waste production and waste management - kept by the marshal of a voivodeship on the grounds of article 37 section 6 of the Act on Waste of 2001;

${ }^{27}$ Kept in the computer system under the name: ,Voivodeship Waste System'. 
2) the central data ${ }^{28}$, concerning waste production and waste management - kept by the minister competent for the environmental matters on the grounds of article 37 section 10 of the Act on Waste of 2001;

3 ) the register of entities introducing batteries and accumulators and operating recycling plants of waste batteries or waste accumulators - kept by the Chief Inspectorate for Environmental Protection on the grounds of article 22 section 1 of the Act on Batteries and Accumulators.

According to $\$ 4$ section 1 of the resolution of the Minister of the Environment of 10 November 2011 concerning the essential scope of information subject to obligatory collection and processing and the method on keeping the central and the voivodeship database concerning waste production and waste management ${ }^{29}$, the central and the voivodeship database are kept in the form of database accessible by electronic means. Article 82 section 1 of the Act of 2012 corresponds with this regulation, according to which the Database shall be kept in teleinformatic system. However, there has been no resolution so far, issued by the Minister competent for environmental issues, on the grounds of article 84, whose objective is to regulate in detail the technical side of the Database.

\subsection{Special rules of management of certain types of waste (Section VII of the Act)}

The equivalent of Section VII of the new Act was Chapter 5 of the Act on Waste of 2001. The necessity to include in Section VII those types of waste results from their content (waste containing $\mathrm{PCB}$, waste coming from the process of titanium dioxide production), the circumstances of production (medical waste, veterinary waste, waste coming from accidents), planned destination within the scope of recovery (urban waste sludge) or prevention (metal waste). At the same time, several binding directives within this scope are implemented by means of the regulations of Section VII.

On account of the implementation of the main Act on Waste of 2012, which is new for the branch of the environmental protection law, and especially Section VII concerning special rules for the management of some

Kept in the computer system under the name: ,Central Waste System'.

29 Journal of Laws of 2011, No 257, item 1547 (repealed as of 23 January 2013). 
types of waste, it should be once more stressed that the legislator did not try to consolidate in one act the provisions concerning such waste as: municipality waste, mining waste, waste electric and electronic equipment, packaging waste, end-of-life vehicles, or waste batteries and accumulators. Replacing the previous main act on waste after 11 year, the effort should have been made, because the former legislative method based on the model 'new EU directive concerning a given sort of waste - new specific act' weakens the effectiveness of applying the law on waste.

\subsection{The requirements concerning the conduct of waste recycling activities (Section VIII of the Act)}

Taking into account the risk related to the transformation of waste within waste recycling processes, the legislator introduces the requirement to employ experts on the position of a manager, respectively of a waste landfill, incinerator or co-incinerator. The testing of knowledge and competences of people in order to fulfil the above mentioned requirement is realised in the way defined in Section VIII Chapter 3 ('Qualifications in the scope of waste management').

In Section VIII Chapter 1, the legislator presented the provisions implementing the Directive of the Council of Europe 1999/31/EC of 26 April 1999 on the landfill of waste. Landfilling of waste is the process of neutralisation. Within the hierarchy of methods of conduct with waste, according to article 18 section 6 , only waste which can not be neutralised in any other way because of technological reasons or is ecologically or economically unjustified should be disposed of. In the Act on Waste, there is a legal definition of a 'waste landfill' but there is no separate definition of 'landfilling'.

Therefore, in accordance with article 3 section 1 point 25 , 'waste landfill' is 'facility allotted for waste landfilling' ${ }^{30}$. Whereas, the EU legislator

30 On the grounds of article 3 point 3 of the Act on Building Law, a waste landfill is classified as ,a structure', defined as , any building object which is neither a building nor a small architectural object, such as: airports, roads, railroads, bridges, trestle bridges, tunnels, technical facilities networks, free-standing aerial masts, free-standing advertising structures permanently connected to the ground, earthen structures, defence fortifications, protection structure, hydraulic engineering structures, reservoirs, free-standing industrial installations 
commented wider in this scope, indicating in article 2 point g) of the Directive 1999/31 that a 'waste landfill' means a 'waste disposal site for the deposit of the waste onto or into land, including:

- internal waste disposal sites (i.e. landfill where a producer of waste is carrying out its own waste disposal at the place of production), and

- a permanent site (i.e. more than one year) which is used for temporary storage of waste,

but excluding:

- facilities where waste is unloaded in order to permit its preparation for further transport for recovery, treatment or disposal elsewhere, and

- storage of waste prior to recovery or treatment for a period less than three years as a general rule,

- storage of waste prior to disposal for a period less than one year'.

The provisions of Section VIII of the new Polish Act confirm that the Polish legislator uses the notion 'landfilling of waste' in the strict connection with the activity of waste neutralisation, which has an independent and not supporting character. At the same time, according to the definition of 'waste storage' meaning 'temporary storing of waste' expressed in article 3 section 1 point 5 of the Act on Waste, it is currently easier to interpret 'waste disposal' as a long-term or definite activity.

In comparison with the provisions of Chapter 1 Section VIII, it is important to divide waste into following categories:

- hazardous waste (according to article 3 section 4 hazardous waste means waste which displays one or more of the hazardous properties listed in Annex 3);

- inert waste (according to article 3 section 1 point 9 inert waste is waste which does not undergo physical, chemical or biological changes, is non-dissoluble, does not undergo physical or chemical reactions, does not contaminate the environment or does not endanger human health, does not undergo biodegradation and has no adverse effect on matter it is in contact with; a general content of contamination

or technical facilities, sewage treatment plants, waste dumping sites, water treatment plants, back-up structures, pedestrian subways and pedestrian bridges, land technical infrastructures networks, sports structures, cemeteries, monuments, as well as building elements of technical facilities (boilers, industrial furnaces and other facilities) and foundations for installations of machinery and facilities, as separate technical components of objects constituting a utility whole'. 
in that waste and the ability to wash it out, as well as a negative environmental impact of a wash must be substantial, and in particular it does not endanger the quality of surface waters, underground waters, soil and ground);

- non-hazardous waste and inert waste, in case of which, there is no separate definition, is waste not included in either of the two previous categories.

The above-mentioned three categories of waste constitute the criterion of indicating the type of a waste landfill, defining the requirements in the scope of building such facilities and diversifying duties of a landfill manager.

The administrative-legal ration for a landfill includes all three stages described in article 123. Therefore, the administrative decisions shall be divided into:

a) decisions issued in the pre-operation stage - a decision on environmental conditions, a building permit, an integrated permit or a permit for waste recycling, a permit for a waste landfill usage, a decision approving the instruction of a waste landfill exploitation (art. 128),

b) decisions issued in the operation stage - a decision approving the new instruction of a waste landfill operation (article 135 section 3 ), a decision defining the scope and schedule of actions necessary to determine the reasons of changes of monitored parameters and possible dangers to the environment (article 139 section 1), a decision defining the scope and schedule of actions necessary to remove the causes and the results of identified threats to the environment (article 139 section 2), a decision on the suspension of a waste landfill usage (article 140 section 1), a decision on expressing the consent to resume a waste landfill usage (article 140 section 6), a decision expressing the consent to mine waste (article144 section 3), a decision expressing the consent to the closure of a waste landfill or its separate part (article 146 section 2), a decision on the transfer, to the entity interested in taking over a waste landfill, of rights and duties resulting from the decision approving the instruction of waste landfill operation (article 151 section 8 )

c) decisions issues in the post-operation stage - a decision on the expiration of a decision approving the instruction of a waste landfill operation (article 129 section 7 ). 
In Section VIII Chapter 1, the legislator has not consolidated all the solutions concerning waste storage. The specific provisions in this scope are also defined in the Act on Geological and Mining Law and in the Act on Mining Waste.

In Section VIII Chapter 2, the Directive 2000/76/EC of the European Parliament and of the Council of 4 December 2000 on the incineration of waste was implemented ${ }^{31}$. The Directive 2000/76 was repealed as of 7 January 2014 on the grounds of article 81 section 1 of the Directive 2010/75/EC of the European Parliament and of the Council of 24 November 2010 on industrial emissions (integrated pollution prevention and control $)^{32}$. The issues concerning waste incineration were described in Chapter IV of the new Directive 2010/75 ('Special provisions for waste incineration plants waste and co-incineration plants' - articles 42-55).

Apart from the mentioned directives concerning waste incineration, the Regulation No 1013/2006 of the European Parliament and of the Council of 14 June 2006 on shipment of waste also plays an important role. The EU legislator indicated in point (39) of the Directive 2008/98 that 'according to the Regulation No 2013/2006, Member States may take the measures necessary to prevent shipments of waste which are not in accordance with their waste management plans. By the way of derogation from that Regulation, Member States should be allowed to limit incoming shipments to incinerators classified as recovery, where it has been established that national waste would have to be disposed of or that waste would have to be treated in a way that is not consistent with their waste management plans. It is recognized that certain Member States may not be able to provide a network comprising the full range of final recovery facilities within their territory'. The need to recycle own waste with the use of incinerators with respect to the proximity rule and self-sufficiency within the network of national waste incineration plants is a priority task in the case of the incoming shipment of waste from other states to incinerators on the territory of that state. However, the limitation of incoming shipment of waste to the state concerns only 'incinerators classified as recovery'.

Section VIII Chapter 2 is organised in the following way:
OJ L 332, 28.12.2000, p. 91-111.
32 OJ L 334, 17.12.2010, p. 17-119. 
- general provisions concerning the conditions of operating waste incineration - article 155 and articles 157-159;

- the obligations of the operator of an incineration plant or coincineration plant - articles 156 and 160;

- penal actions (the suspension of operations in the incineration or coincineration plant) - articles 161-162;

- definite or partial shut-down of the incineration plant of waste included in the catalogue in article 163 in accordance with the provisions of Section VIII Chapter 2;

\subsection{Penal provisions and administrative fines (Section X of the new Act)}

In Section X of the Act on Waste, the issues concerning legal liability in the scope of the duties resulting from the Act have been regulated. For the needs of waste management, the legislator used in Section $\mathrm{X}$ two legal regimes: a) criminal law liability (Chapter 1 Section X - articles 171-193) and b) administrative law liability with financial sanctions (Chapter 2 Section X - articles 194-202). In both cases the regimes are based on the conception of linked norms - a sanctioned norm and a sanctioning norm. In the case of both regimes sanctioned norms are among the provisions of primary sections of the Act. In the hypothesis of these norms the addressees of obligations and sanctions being their disposition are defined. Whereas, in Section $X$ there are joined to them sanctioning norms. The hypothesis of the sanctioning norm from Section $\mathrm{X}$ is the fact of violating the sanctioned norm, whereas in its disposition the sanctions for the addressee were defined. There are two kinds of sanctions - penal sanctions and administrative financial sanction.

While analysing the usefulness of both regimes of legal liability from the point of view of the environment and its protection, it may be indicated that in the case of penalliability its repressive and prevention-educational function are of prime importance, which, however, are subject to general limitations resulting from basing this legal regime on the rule of guilt and formalized and time-consuming mode of inflicting punishment by a criminal court. On the other hand administrative-legal liability, which is objectivised and enforced by administrative bodies, first realizes general functions of legal liability: protective, affirmative-motivating and compensative, as well as, 
serves the effective realisation of general rules of environmental protection law: the rule of prevention and caution and the 'pollutant pays principle'. In Section X, the legislator uses the penal liability for punishable offences and in the case of administrative liability financial penalty.

\section{Conclusion}

The Polish law on waste constitutes a dynamically developing part of the environmental protection law. It stays under a great influence of both international law and EU law. The Polish legislator, while trying to fulfil the growing requirements concerning waste management resulting from the EU environmental protection priorities, applies the conservative approach, limited to a simple reaction to subsequent requirements. As mentioned before, the conservative approach is visible above all in applying the model: 'new EU directive - new Polish act', the result of which is the growing number of acts on waste law. The number of acts and the lack of full correlation between their content is becoming a serious problem, both from the point of view of entities operating in the scope of waste management and public authorities (by applying those regulations by public administrative bodies).

The new Act on Waste of 2012 is in this context a step in the right direction. There is no doubt that it is necessary to adjust the Polish law on waste to binding EU solutions. However, it is impossible not to notice that the Polish legislator did not use the opportunity connected with the implementation of the frame Directive 2008/98 to systematize provisions on waste in a clear and consistent way. As a result, the new Act on Waste of 2012, despite implementing several new solutions, it does not cover many issues concerning waste management, which are regulated in specific acts. Therefore, the Polish law on waste is still waiting for the Polish legislator to start large-scale analysis aiming at developing a comprehensive and coherent approach towards the issues of waste management in accordance with the rule of sustainable development. 